Original research article

\title{
Malnutrition in older people in clinical nursing diagnosis
}

\author{
Lubica Poledníková *, Alica Slamková, Andrea Solgajová, Dana Zrubcová \\ Constantine the Philosopher University in Nitra, Faculty of Social Sciences and Health Care, Department of Nursing, Nitra, Slovak Republic
}

\begin{abstract}
The aim of this study was to validate the actual nursing diagnosis of imbalanced nutrition: less than body requirements in older patients. It is a retrospective and comparative study. To validate the nursing diagnosis, we used the Fehring's models: the Diagnostic Content Validity Model and the Patient-Focused Clinical Diagnostic Validity Model. They were used to find out the significance of the defining characteristics of the nursing diagnosis of imbalanced nutrition: less than body requirements. After data collection, we calculated a weighted score (WS) for each defining characteristic. There were two samples in the study. The first sample $\left(n_{1}\right)$ consisted of 101 nurses - experts according to the modified Fehring's criteria. The second sample $\left(n_{2}\right)$ consisted of 50 hospitalized older patients who had fewer than 17 points (a score indicative of malnutrition) in the first and second parts of the standardised nutrition assessment tool - the MNA (Mini Nutritional Assessment). Out of 22 items, the nurses rated one item as major: food intake less than recommended daily allowance (0.87). In the sample of patients, they rated six items out of 17 as major. They are: insufficient interest in food (0.83), food aversion (0.82), alteration in taste sensation (0.78), decreased body weight (0.77), weight loss with adequate food intake (0.77), and food intake less than recommended daily allowance (0.76). As a result of this study, we suggest considering the inclusion of measurement tools that focus on early detection of malnutrition in all hospitalised older people with lower food intake.
\end{abstract}

Keywords: Defining characteristic; Malnutrition; Nursing diagnosis; Older person; Validation

\section{Introduction}

Malnutrition in old age is a multifactorial problem associated with increased morbidity, mortality and high healthcare costs (Guyonnet and Rolland, 2015; Rentero Redondo et al., 2015). The seriousness of the problem is underlined by its high prevalence in multiple healthcare settings referenced in both domestic and foreign publications. According to Zadák (2004), malnutrition occurs in about $50 \%$ of older people, and the frequency of malnutrition increases with the incidence of chronic diseases (85\%). At the age of more than 80 years, mild manifestations of malnutrition occur in almost all individuals regardless of their socioeconomic status (Klevetová and Topinková, 2003). The reported prevalence of malnutrition in hospitals in Europe is also widespread, with estimates of up to $100 \%$ of patients, depending on the criteria used to identify malnutrition (Kyle et al., 2003). "Furthermore, malnutrition has been an issue in long-term care facilities, where research shows the prevalence of $54 \%$ in new residents, and $23 \%$ to $85 \%$ in other residents of these facilities" (Martinický, 2008; translated by the study authors).

The term malnutrition comes from a combination of two Latin words: "mal" (wrong) and "nutria" (nurture or nourish). The term, however, is perceived primarily as undernutrition, and not as bad nutrition in general, which also expresses excessive food intake (Charvát and Kvapil, 2006). Svačina et al.
(2010), Zadák (2004) and other authors characterise malnutrition as a pathological condition caused by a lack of nutrients. In the nursing terminology, a patient's condition of malnutrition or inadequate nutrition which results in malnutrition is expressed by the nursing diagnosis of imbalanced nutrition: less than body requirements (00002) according to the taxonomy (Herdman and Kamitsuru, 2014). The nursing diagnosis was included in the system of nursing diagnoses in 1975 and edited in 2000. It is in the domain 2 - Nutrition, and the class 1 - Ingestion as an actual nursing diagnosis. It is defined as "intake of nutrients insufficient to meet metabolic needs" (Herdman and Kamitsuru, 2014, p. 161). Carpenito-Moyet (2004, p. 415) defines it as a "state in which a person who is not NPO experiences or is at risk of experiencing reduced weight related to inadequate intake or metabolism of nutrients for metabolic needs". Detecting the nursing diagnosis of imbalanced nutrition (less than body requirements) includes defining characteristics and related factors. Defining characteristics are manifestations of a patient's problem. For the studied diagnosis, Carpenito-Moyet (2004) divides them into two groups according to their importance: major, which must be present, and minor, which may be present.

Herdman and Kamitsuru (2014, p. 161) state the need of the presence of the following defining characteristics: "Abdominal cramping, abdominal pain, alteration in taste sensation, body weight $20 \%$ below ideal weight range, capillary fragility, diarrhoea, excessive hair loss, food aversion, food intake

\footnotetext{
* Author for correspondence: L'ubica Poledníková, Constantine the Philosopher University in Nitra, Faculty of Social Sciences and Health Care, Department of Nursing, Kraskova 1, 94974 Nitra, Slovak Republic; e-mail: lpolednikova@ukf.sk http://doi.org/10.32725/kont.2019.040 
less than recommended daily allowance, hyperactive bowel sounds, insufficient information, insufficient interest in food, insufficient muscle tone, misinformation, misperception, pale mucous membranes, perceived inability to ingest food, satiety immediately upon ingesting food, sore buccal cavity, weakness of muscles required for mastication, weakness of muscles required for swallowing, weight loss with adequate food intake."

In clinical practice, a patient's nutritional status is always assessed globally, because there is no simple and universal parameter for diagnosis of malnutrition. In old age, such assessment can be complicated by changes that are normally found in ageing, and lack of standards for the interpretation of measurements. In domestic and foreign literature, multiple tools for detection of malnutrition are offered. According to Bauer and Sieber (2007), it is possible to diagnose malnutrition in older patients by simple parameters such as weight loss, BMI and peroral intake. Available screening and assessment tools such as the Mini Nutrition Assessment (MNA) and the $\mathrm{Nu}-$ tritional Risk Screening 2002 (NRS 2002) focus on diagnosis standardisation and early detection of malnutrition. While the MNA appears to be more suitable for older citizens in the community, the NRS 2002 offers benefits for the hospital environment. Vanderwee et al. also report the use of the MNA for detection of malnutrition in hospitalised older people. (2010). Comparisons of the extent of malnutrition with the use of measurement scales with various criteria used in various diagnostic groups and healthcare environments are hampered by a lack of universally agreed methods to detect risk of malnutrition and malnutrition (Saturday et al., 2004). Recognizing the defining characteristics of the nursing diagnosis of imbalanced nutrition: less than body requirements, the nurses may contribute to an early detection of a nutritional problem, and by appropriate interventions they can prevent the serious consequences of malnutrition.

\section{Materials and methods}

The aim of the study was to find out which defining characteristics nurses in the Slovak Republic consider to be significant for the validation of the nursing diagnosis of imbalanced nutrition: less than body requirements (Herdman and Kamitsu$\mathrm{ru}, 2014$ ) in older patients, and which of them are the most frequently present in accordance with the statements by older patients.

Two Fehring's models, the Diagnostic Content Validity (DCV) Model and the Patient-Focused Clinical Diagnostic Validity (CDV) Model (Fehring, 1986), were used for validation of the nursing diagnosis. Data collection was conducted in two samples. In the sample of nurses - experts, we used a measurement tool which contained 22 defining characteristics of the nursing diagnosis of imbalanced nutrition: less than body requirements (Herdman and Kamitsuru, 2014), and demographic data. The nurses rated the occurrence of defining characteristics of the diagnosis in older people with malnutrition retrospectively on the Likert-type scale from 1 to 5 ( 1 - The defining characteristic is not characteristic - no significance, 2 - very little characteristic - small significance, 3 - a little characteristic - moderate significance, 4 - highly characteristic - high significance, 5 - very characteristic - highest significance). In the second sample, the patients rated the current occurrence of 17 defining characteristics of the diagnosis on the same Likert-type scale as the nurses. Five characteristics were discarded from the original scale because the patients could not describe them accurately. To select a sample of patients, we used a standardised nutrition assessment tool - the MNA Part 1 and 2, in which the respondents had fewer than 17 points (a score indicative of malnutrition). The research was conducted from October 2017 to April 2018. The measurement tool was distributed among the nurses by a personal contact of the study authors and mediated through the mandated person, and among the patients by a personal contact of the study authors. The nurses were trained for data collection.

For statistical data analysis, we used descriptive statistics. The basic statistical values (arithmetic mean $-x$, standard deviation $(S D)$ and weighted score (WS) were calculated for each defining characteristic. The weighted score was calculated by the sum of the values assigned to each response and dividing it by the number of responses. Values were assigned as follows: $5=1 ; 4=0.75 ; 3=0.5 ; 2=0.25 ; 1=0$ (Fehring, 1986). The major defining characteristics were with WS > 0.75; minor were with WS more than 0.5 to 0.75 , and insignificant were with WS 0.5 and less. The total DCV score was obtained from the sum of the ratings of the individual defining characteristics and the calculation of the mean. The total score did not include those that had a weighted score value of 0.5 or less.

In the study, there were two samples created by non-probability sampling based on the criteria set. The first sample $\left(n_{1}\right)$ consisted of 101 nurses - experts who had a minimum of four points according to the modified Fehring's criteria (Zeleníková and Žiaková, 2010). The sample characteristics include: gender, education, workplace, specialty, age, number of years of clinical practice experience, score by modified criteria, etc. (Table 1). The sample consisted of nurses working in faculty hospitals in Nitra (51) and Nové Zámky (32), and 18 nurses from the Town Hospital in Topol'čany. The second sample $\left(n_{2}\right)$ consisted of 50 patients older than 60 years of age hospitalised in the FH Nitra in the Clinic of Internal Medicine and the Department of Oncology who had fewer than 17 points in the 1st and 2nd part of the MNA. The sample characteristics include: gender, age, department of hospitalisation, and score indicative of malnutrition (Table 2).

\begin{tabular}{|c|c|c|}
\hline Characteristic & $n$ & $\%$ \\
\hline \multicolumn{3}{|l|}{ Gender } \\
\hline Women & 99 & 98 \\
\hline Men & 2 & 2 \\
\hline \multicolumn{3}{|l|}{ Education } \\
\hline \multicolumn{3}{|l|}{ Secondary School of Nursing, Higher } \\
\hline Vocational Education & 32 & 32 \\
\hline University - Level 1 & 37 & 36 \\
\hline University - Level 2 and 3 & 32 & 32 \\
\hline \multicolumn{3}{|l|}{ Specialty } \\
\hline Yes & 47 & 47 \\
\hline No & 54 & 53 \\
\hline \multicolumn{3}{|l|}{ Diploma, rigorous thesis } \\
\hline Yes & 5 & 5 \\
\hline No & 96 & 95 \\
\hline \multicolumn{3}{|l|}{ Workplace } \\
\hline Clinic of Internal Medicine (dept.) & 50 & 50 \\
\hline Clinic of Oncology & 22 & 22 \\
\hline Cardiology Clinic & 16 & 16 \\
\hline Intensive Care Unit & 13 & 12 \\
\hline Age & \multicolumn{2}{|c|}{$x=43 ; S D=9.3 ; \min .25, \max .63$} \\
\hline Modified score for an expert & \multicolumn{2}{|c|}{$x=5.9 ; S D=1.98 ; \min .4, \max .12$} \\
\hline
\end{tabular}


Table 2. Characteristics of the sample of patients $\left(n_{2}=50\right)$

\begin{tabular}{|c|c|c|}
\hline Characteristic & $n$ & $\%$ \\
\hline \multicolumn{3}{|l|}{ Gender } \\
\hline Women & 30 & 60 \\
\hline Men & 20 & 40 \\
\hline \multicolumn{3}{|l|}{ Hospitalisation } \\
\hline Clinic of Internal Medicine & 2 & 58 \\
\hline Department of Oncology & 21 & 42 \\
\hline Age & \multicolumn{2}{|c|}{$x=73 ; S D=6.7 ; \min .61, \max .90$} \\
\hline $\begin{array}{l}\text { Score indicative of } \\
\text { malnutrition }\end{array}$ & \multicolumn{2}{|c|}{$x=15.3 ; S D=0.82 ; \min .13, \max .16 .5$} \\
\hline
\end{tabular}

\section{Results}

Based on the analysis of the nurses' $\left(n_{1}\right)$ and patients' $\left(n_{2}\right)$ responses, we created a table in which we state the defining characteristics for the validated nursing diagnosis. Furthermore, we compare the inclusion of the defining characteristics among the major (WS > 0.75), minor (WS > 0.5 to 0.75), and insignificant (WS $\leq 0.5$ ) ones in both samples. For comparison, we distinguished the significance of the characteristics by a colour label (major - red, minor - black, insignificant - green).
Out of 22 items, the nurses rated one item as major: food intake less than recommended daily allowance (0.87). In the sample of patients, they rated six items out of the total of 17 as major: insufficient interest in food (0.83), food aversion (0.82), alteration in taste sensation (0.78), decreased body weight (0.77), weight loss with adequate food intake (0.77), and food intake less than recommended daily allowance (0.76). The nurses rated 18 items as minor; the patients rated nine items as minor. The nurses rated three defining characteristics and the patients rated two defining characteristics with the lowest significance; both samples discarded the defining characteristic excessive hair loss (Table 3 ).

\section{Discussion}

This research study focuses on confirmation of the validity of the nursing diagnosis of imbalanced nutrition (less than body requirements) in older patients through the identification of clinical indicators according to NANDA I, the defining characteristics of the nursing diagnosis. The literature describes multiple symptoms of malnutrition and standardised measurement tools that include these symptoms, or their causes. According to Ham (1994), symptoms such as cheilosis or stomatitis suggest nutritional deficiency in the area of B-group vitamins; dry mouth as well as changes in skin turgor may be a sign of dehydration; the evidence of insufficient subcutaneous fat and loose skin are signs of weight loss; and bruises,

Table 3. The defining characteristics identified by the nurses and patients as major, minor and insignificant

\begin{tabular}{|c|c|c|c|c|c|c|}
\hline \multirow[t]{2}{*}{ Defining characteristics } & \multicolumn{3}{|c|}{ Nurses } & \multicolumn{3}{|c|}{ Patients } \\
\hline & Mean & $S D$ & WS & Mean & $S D$ & WS \\
\hline Abdominal cramping & 3.24 & 0.98 & 0.56 & 3.96 & 0.73 & 0.74 \\
\hline Abdominal pain & 3.91 & 0.79 & 0.73 & 3.88 & 0.72 & 0.72 \\
\hline Alteration in taste sensation & 3.78 & 0.73 & 0.70 & 4.12 & 1.02 & 0.78 \\
\hline Decreased body weight & 3.60 & 0.90 & 0.65 & 4.08 & 0.78 & 0.77 \\
\hline Capillary fragility & 3.00 & 0.89 & 0.50 & & & \\
\hline Diarrhoea & 3.49 & 0.88 & 0.62 & 3.24 & 1.29 & 0.56 \\
\hline Excessive hair loss & 2.30 & 0.79 & 0.34 & 2.20 & 0.83 & 0.30 \\
\hline Food aversion & 3.83 & 0.75 & 0.71 & 4.26 & 0.88 & 0.82 \\
\hline Food intake less than recommended daily allowance & 4.50 & 0.66 & 0.87 & 4.02 & 0.87 & 0.76 \\
\hline Hyperactive bowel sounds & 3.29 & 0.73 & 0.57 & 2.78 & 0.84 & 0.45 \\
\hline Insufficient information & 3.40 & 0.79 & 0.60 & 3.04 & 1.01 & 0.51 \\
\hline Insufficient interest in food & 3.76 & 0.67 & 0.69 & 4.30 & 0.99 & 0.83 \\
\hline Insufficient muscle tone & 3.97 & 0.62 & 0.74 & & & \\
\hline Misinformation & 3.36 & 0.81 & 0.59 & & & \\
\hline Misperception & 2.77 & 0.72 & 0.44 & & & \\
\hline Pale mucous membranes & 3.58 & 0.59 & 0.65 & & & \\
\hline Perceived inability to ingest food & 3.34 & 0.78 & 0.58 & 3.40 & 0.83 & 0.60 \\
\hline Satiety immediately upon ingesting food & 3.90 & 0.71 & 0.73 & 3.66 & 1.21 & 0.67 \\
\hline Sore buccal cavity & 3.04 & 0.89 & 0.51 & 3.22 & 0.97 & 0.56 \\
\hline Weakness of muscles required for mastication & 2.98 & 0.89 & 0.55 & 3.22 & 1.04 & 0.56 \\
\hline Weakness of muscles required for swallowing & 3.18 & 0.84 & 0.54 & 3.12 & 1.10 & 0.53 \\
\hline Weight loss with adequate food intake & 3.36 & 0.86 & 0.59 & 4.08 & 0.85 & 0.77 \\
\hline
\end{tabular}

$S D$, standard deviation; WS, weighted score. The total DCV score in the sample of nurses was 0.64 and in the sample of patients it was 0.68 . 
oedema and poorly healing wounds may indicate hypoproteinaemia. Laboratory measurements, in particular decreased levels of serum proteins, are nowadays considered to be markers of the intensity of a disease rather than indicators of a current nutritional status (Wilhelm et al., 2001). Kayashita et al. (2013) state that serum albumin, blood haemoglobin and total lymphocyte count are good biomarkers for detection of malnourished patients with acute diseases. An overall picture of the nutritional status is completed by a nutritional history that highlights the increased risk factors. Most of the aforementioned symptoms are present only in severe malnutrition. However, detection of clinical signs and symptoms of malnutrition at the beginning of its development can be a tool for preventing the serious consequences of nutritional deficiency. The nursing diagnosis, as defined by Herdman and Kamitsuru (2014), expresses not only the actual malnutrition, but also the risk of it. Therefore, based on the present risk factors of malnutrition as well as the first clinical manifestations, nurses can detect the development of malnutrition in time.

In general, it can be stated that malnutrition results from insufficient or inadequate nutrition, which leads to decreased body weight, and other comprehensive metabolic and somatic changes. The definitions of malnutrition describe it as a condition caused by a lack of nutrients (Svačina et al., 2010; Zadák, 2004). Furthermore, the definition is supported by our finding that the defining characteristic of 'food intake less than recommended daily allowance' was rated as major in both samples. Carpenito-Moyet (2004) also included this characteristic among the major characteristics that must be present for confirmation of the studied diagnosis. In the validation study by Teixeira et al. (2016), the defining characteristic - food intake less than recommended daily allowance, occurred most frequently (specifically, in $47 \%$ of children). Although childhood and old age are two age-boundary (distant) periods, malnutrition increases in these age groups because of a higher sensitivity to the symptoms of diseases and more frequent complications for a weakened or undeveloped immune system. The relationship between insufficient food intake (less than $50 \%$ of the calculated daily allowance) and other symptoms of malnutrition, such as lower total cholesterol, albumin and prealbumin, are described in the study by Sullivan et al. (1999). Kayashita et al. (2013) also state the findings of reduced food intake as an important indicator of malnutrition in hospitalised patients in combination with ageing and fall history. The question about changes in food intake is included in some form in most measurement tools for detection of malnutrition, with a focus not only on actual intake, but also food intake in a recent period (weeks, months). In their cross-sectional study, Alzahrani et al. (2016) state decreased food intake in up to $56.9 \%$ of the geriatric patients who were included in the category of the undernourished, or those at risk of undernutrition, based on the MNA testing. The quantity of eaten food is associated with satiety too. In the sample of nurses, the defining characteristic - satiety immediately upon ingesting food - was among the characteristics with the fifth highest weighted score (0.73). In the sample of patients, this value was slightly lower (0.67). Teixeira et al. (2016) found that this clinical indicator showed high sensitivity levels, indicating good diagnostic accuracy for identification of the nursing diagnosis of imbalanced nutrition: less than body requirements in childhood.

In our study, the defining characteristics with the highest weighted scores in the sample of patients were: insufficient interest in food, food aversion, and alteration in taste sensation. They are subjective sensations which result in lower food intake; and in the literature they are often stated as causes of malnutrition. These characteristics were rated as minor in the sample of nurses, which relates to the focus rather than the objective, measurable indicators of inadequate nutrition, e.g. the amount of food eaten. The question about appetite is also part of some screening tools for detection of malnutrition, e.g. the MNA. Teixeira et al. (2016) state insufficient interest in food as one of the indicators which showed the highest accuracy of diagnosis of malnutrition in early childhood; in our study, the patients rated it with the highest score $(0.83)$. In the malnutrition testing in the hospitalised geriatric patients, Wanderwee et al. (2010) identified three factors - alteration in taste sensation, difficulty swallowing, and a stay in an institution - that were strongly associated with malnutrition or its risk. In our sample of patients, alteration in taste sensation had a score of up to 0.78 . In the systematic cross-sectional study by van Der Pols-Vijlbrief et al. (2014), they found strong evidence of the relationship between malnutrition and decreased appetite. Similarly, with the use of a screening tool, Tannen and Lohrmann (2013) found a loss of appetite in up to $56.6 \%$ of patients who were included in a group at risk of malnutrition. In the retrospective study, Almeida et al. (2008) identified loss of appetite as the most common aetiology of the studied nursing diagnosis. The defining characteristic - food aversion had the second highest weighted score in our sample of patients. Malafarina et al. (2013) mention the term 'anorexia of ageing', which is caused by physiological processes of ageing and factors prevailing in older people, such as comorbidity and polypharmacy. The senses of taste and smell diminish with age. According to Ahmed and Haboubi (2010), the decline in sense of smell decreases food intake in older people and can influence the type of food eaten and causes reduced interest in food intake. Anorexia of ageing is prevalent among hospitalised and institutionalised older people. It is associated with comorbidity and represents a predictive factor in malnutrition. According to Soenen and Chapman (2013), physiological anorexia of ageing can be one of the factors that cause unintentional weight loss. As a result of our findings, we consider insufficient interest in food, food aversion or alteration in taste sensation to be significant defining characteristics, particularly if they are present in older patients in whom anorexia may be associated with age and institutionalisation. There is a clear relationship between these defining characteristics and the amount of consumed food, so the nurse should detect their presence.

Decreased body weight and weight loss with adequate food intake were other defining characteristics perceived as major by the patients in our study. In the sample of nurses, they were rated as minor. Most measurement tools for detection of malnutrition (the MNA, the NRS, etc.) include anthropometric measurements such as weight, height and BMI (Body Mass Index) calculation, as well as questions about weight loss in the previous three to six months. Similarly, Bauer and Sieber (2007) emphasise the significance of these simple parameters in the diagnosis of malnutrition in older people. However, the frequent problem of anthropometric measurements is the impossibility of their use in older people who cannot be weighed or measured because of their health characteristics. Stratton et al. (2006) also draw attention to this shortcoming; they emphasise the necessity to replace the objective parameters by subjective indicators of nutritional status. Mikula and Hluchová (2005) warn that weight loss can be masked by changes in fluid status, dehydration, water retention (oedema, ascites), or tumour growth. In their research study, Kayashita et al. (2013) concluded that the BMI is not valid as a biomarker of malnutrition in newly hospitalised older people, unlike weight loss in combination with difficulty swallowing and fever. Meijers 
et al. (2010) point out the conclusions of the DELPHI study in which the experts in defining the elements of malnutrition stated the following as important: involuntary weight loss, body mass index, and no nutritional intake. Despite these conclusions, there has been no full consensus on the elements defining malnutrition, and there is a need for further discussions at the international level.

In our study, insufficient muscle tone was only rated by the nurses. Its weighted score was on the boundary between the major and minor defining characteristics. However, its occurrence may not relate only to malnutrition. According to Thompson (2009), ageing is associated with a progressive decline in muscle mass, strength and quality, which is a condition described as sarcopenia. Physical inactivity and loss of appetite that leads to insufficient nutrient intake, are some other reasons leading to muscle loss in older adults (Doherty, 2003; Jones et al., 2009). We analysed the presence of the defining characteristics - weakness of muscles required for mastication and swallowing, which influence mastication and swallowing - in both samples. The respondents in both samples included them among the minor defining characteristics with a minimum weighted score difference. Mastication difficulties relate to the dentition status, functionality of the prosthesis, etc., which are the factors that deteriorate with age. Hickson (2006) emphasises that oral health and teeth significantly affect food intake and generally deteriorate with age. This is supported by the findings of Nakanishi et al. (1999) in which people without teeth reported greater difficulties in consuming a range of food; there were problems with mastication; and dry mouth was much more common. Swallowing difficulties increase in relation to age, but are mainly caused by oesophageal diseases, neurological disorders, inflammatory myopathies, or even drugs taken by an older person (Zadák, 2004). Vanderwee et al. (2010) state their findings on the prevalence of swallowing difficulties and their strong association with malnutrition in older patients. Similarly, Kinney and Allison (2002) include mastication and swallowing difficulties in the factors associated with malnutrition. The inclusion of the characteristics required for mastication and swallowing by the respondents in our study was on the boundary between the minor and discarded characteristics. This leads us to the conclusion that both the nurses and patients mostly did not notice such difficulties. Also, in the systematic literature review, Van der Pols-Vijlbrie et al. (2014) found no evidence for the association between difficulty with mastication and poor nutrition.

In our study, the clinical indicators - abdominal pain and abdominal cramps - were rated as minor in both samples. We consider them to be rather etiological factors due to the abdominal discomfort they result in followed by a lack of appetite. Their high prevalence is likely to be related to the health status of the studied sample.

The presence of diarrhoea in malnutrition is a consequence of intestinal atrophy, and structural and functional changes resulting in further deterioration of the nutritional status (Zadák, 2004). In our study, the respondents in both samples included diarrhoea in the minor defining characteristics with lower weighted scores. We found no comparison for the presence of diarrhoea as a clinical symptom of malnutrition in other studies.

Svačina et al. (2010) and Zadák (2004) state that one of the consequences of chronic malnutrition is also anaemia as a result of decreased iron intake, and leucopoenia, which leads to more frequent infectious diseases. The defining characteristic of pale mucous membranes was only studied in the sample of nurses; the defining characteristic of sore buccal cavity was rated in both samples, and was included in the minor characteristics. However, their prevalence in old age may relate not only to inadequate nutrition but the overall health status in older patients.

The defining characteristic of insufficient information was rated as minor in both samples, with a higher score in the sample of nurses. The defining characteristic of misinformation was rated only by the nurses, and produced a similar result. These characteristics are rather etiological factors for nutritional imbalance, similar to misperception (false perception), which was included among the characteristics with the lowest significance by the nurses. In relation to this phenomenon, Teixeira et al. (2016) and Mink et al. (2010) suggest that for some people it is important to pay less for a larger amount of lower-quality foods that satiate immediately and also induce a belief of good nutrition.

Besides misperception, the nurses identified capillary fragility and excessive hair loss as the characteristics with the lowest significance; the patients identified excessive hair loss and hyperactive bowel sounds. Such an inclusion of the defining characteristics is likely to be related to their low specificity; besides malnutrition, they may also be present in other situations and conditions occurring in old age in a higher extent.

In our study, to validate the nursing diagnosis of imbalanced nutrition: less than body requirements (Herdman and Kamitsuru, 2014), we identified one major defining characteristic in the sample of nurses and six in the sample of patients. Both samples included the defining characteristic of 'food intake less than recommended daily allowance' in the major defining characteristics for the studied nursing diagnosis. Our findings emphasise the importance of food intake detection and monitoring strategies during hospitalisation, which was also emphasised by Dias de Araújo et al. (2014). The nurses rated most of the defining characteristics as minor. In our opinion this is because several of them may indicate other nursing problems in older patients (diarrhoea, hyperactive bowel sounds, pale mucous membranes, etc.), or are rather in etiological relationship with the studied nursing diagnosis (abdominal pain, insufficient information, weakness of muscles required for mastication or swallowing).

In the study, we were limited by the sample size and orientation to only one region of the Slovak Republic. In the context of further research, it is necessary to focus on testing of the scales, and detection and comparison of the significant defining characteristics in the various regions of the Slovak Republic. We also recommend further validation of the diagnosis, focusing on the older population in Europe and elsewhere.

\section{Conclusions}

Malnutrition, in nursing terminology imbalanced nutrition: less than body requirements, is a serious problem of old age and an important part of nursing care. Therefore, the priority role of nurses is its early detection on the basis of significant defining characteristics as well as related factors. There are multiple signs and symptoms of malnutrition; and usually a combination of methods (anthropometric, dietetic, clinical) is used for their detection, which may be more appropriate than the use of only one of them to assess nutritional status. This is especially true in older patients whose age and health characteristics make the detection of malnutrition more difficult. By validating the nursing diagnosis, we found an agreement between the samples in one main characteristic - food intake less than recommended daily allowance, which is characteris- 
tic for the studied nursing diagnosis. Due to this, we suggest considering the inclusion of measurement tools that focus on early detection of malnutrition in all hospitalised older people with lower food intake. Validation of the nursing diagnosis of imbalanced nutrition: less than body requirements on the basis of reliable indicators, its early detection, and intervening will help to reduce morbidity, mortality, and healthcare costs.

\section{Conflict of interests}

The authors have no conflict of interests to declare.

\section{Podvýživa seniorov v klinickej ošetrovatel'skej diagnostike}

\section{Súhrn}

Ciel'om štúdie bola validácia aktuálnej ošetrovatel'skej diagnózy Nevyvážená výživa: menej než je potreba organizmu u pacientov vyššieho veku. Práca má charakter retrospektívnej a komparatívnej štúdie. Na validáciu ošetrovatel'skej diagnózy boli zvolené Fehringove modely - Model validity diagnostického obsahu a Na pacienta zameraný model klinickej diagnostickej validity, pomocou ktorých sme zistovali významnost' určujúcich znakov ošetrovatel'skej diagnózy Nevyvážená výživa: menej než je potreba organizmu. Po zbere údajov sme pre každú definujúcu charakteristiku vypočítali vážené skóre (VS). Do výskumu boli zaradené 2 výberové súbory: Prvý výberový súbor $\left(n_{1}\right)$ tvorilo 101 sestier - expertiek podl'a modifikovaných Fehringových kritérií. Druhý výberový súbor $\left(n_{2}\right)$ tvorilo 50 hospitalizovaných pacientov vyššieho veku, ktorí dosiahli menej ako 17 bodov (malnutričné indikačné skóre) v prvej a druhej časti štandardizovaného nástroja na hodnotenie stavu výživy - MNA (Mini Nutritional Assessment). $Z$ celkového počtu 22 položiek sestry označili 1 za hlavnú - príjem potravy je menší, ako je odporúčaná denná dávka $(0,87)$. V súbore pacientov títo označili 6 položiek z celkového počtu 17 za hlavné. Sú to: nezáujem o jedlo $(0,83)$, odpor k jedlu $(0,82)$, zmenená chut' $(0,78)$, znížená telesná hmotnost' $(0,77)$, strata telesnej hmotnosti pri primeranom príjme potravy $(0,77)$, príjem potravy menší, ako je odporúčaná denná dávka $(0,76)$. Vzhl'adom k zisteniam navrhujeme zvážit zaradenie hodnotiacich nástrojov, ktoré sa zameriavajú na včasné rozpoznanie podvýživy u všetkých hospitalizovaných seniorov s menším potravinovým príjmom.

Kl'účové slová: ošetrovatel'ská diagnóza; podvýživa; senior; určujúci znak; validácia

\section{References}

1. Ahmed T, Haboubi N (2010). Assessment and management of nutrition in older people and its importance to health. Clin Interv Aging 9(5): 207-216. DOI: 10.2147/CIA.S9664.

2. Almeida MA, Aliti GB, Franzen E, Thomé EG, Unicovsky MR, Rabelo-Silva ER, et al. (2008). Prevalent nursing diagnoses and interventions in the hospitalized elder care. Rew Latino-Am Enfermagem 16(4): 707-711. DOI: 10.1590/ S010411692008000400009.

3. Alzahrani SH, El Sayed IA, Alshamrani SM (2016). Prevalence and factors associated with geriatric malnutrition in an outpatient clinic of a teaching hospital in Jeddah, Saudi Arabia. Ann Saudi Med 36(5): 346-351. DOI: 10.5144/02564947.2016.346.

4. Bauer JM, Sieber CC (2007). Significance and diagnosis of malnutrition in the elderly. Z Arztl Fortbild Qualitatssich 101(9): 605-609.

5. Carpenito-Moyet LJ (2004). Nursing Diagnosis: Aplication to Clinical Practice. Philadelphia U.S.A.: Lippincott Company.

6. Charvát J, Kvapil M (2006). Praktikum umělé výživy. Praha: UK.

7. Dias de Araújo D, Rodrigues de Carvalho RL, Machado Chianca TC (2014). Nursing Diagnoses identified in the medical records of hospitalized elderly. Invest Educ Enferm 32(2): 225-235. DOI: 10.17533/udea.iee.v32n2a05.

8. Doherty TJ (2003). Invited review: Aging and sarcopenia. J Appl Physiol (1985) 95(4):1717-27. DOI: 10.1152/ japplphysiol.00347.2003.

9. Fehring RJ (1986). Validating diagnostic labels: standardized methodology. In: Hurley ME (Ed.). Classification of nursing diagnoses: Proceedings of the sixth Conference. Mosby: St. Louis, pp. 183-190.

10. Guyonnet S, Rolland Y (2015). Screening for Malnutrition in Older People. Clin Geriatr Med 31(3): 429-437. DOI: 10.1016/j. cger.2015.04.009.

11. Ham RJ (1994). The signs and symptoms of poor nutritional status. Primary Care 21(1): 33-54.

12. Herdman TH, Kamitsuru S (2014). Nursing diagnoses. Definitions and classification 2015-2017. Oxford: Wiley Blackwell.
13. Hickson M (2006). Malnutrition and ageing. Postgrad Med J 82(963): 2-8. DOI: 10.1136/pgmj.2005.037564.

14. Jones TE, Stephenson KW, King JG, Knight KR, Marshall TL, Scott WB J (2009). Sarcopenia - mechanisms and treatments. Geriatr Phys Ther 32(3): 83-89.

15. Kayashita A, Yamato H, Yoshida I, Matsuzaki K, Niki H, Nagae H, Miyamoto K (2013). Evaluation of 14 questions detecting malnutrition in newly hospitalized patients. J Med Invest 60(1-2): 138-145. DOI: 10.2152/jmi.60.138.

16. Kinney JM, Allison SP (2002). Nutrition and ageing. Curr Opin Clin Nutr Metab Care 5(1): 1-3.

17. Klevetová D, Topinková E (2003). Hodnocení malnutrice u seniorů v domáci péči. Sestra 13(4): 24-25.

18. Kyle UG, Pirlich M, Schuetz T, Luebke HJ, Lochs H, Pichard C (2003). Prevalence of malnutrition in 1760 patients at hospital admission: a controlled population study of body composition. Clin Nutr 22(5): 473-481. DOI: 10.1016/SO2615614(03)00049-9.

19. Malafarina V, Uriz-Otano F, Gil-Guerrero L, Iniesta R (2013). The anorexia of ageing: Physiopathology, prevalence, associated comorbidity and mortality. A systematic review. Maturitas 74(4): 293-302. DOI: 10.1016/j.maturitas.2013.01.016.

20. Martinický D (2008). Možnosti riešenia malnutrície u geriatrického pacienta. Kompendium medicíny, VII. slovenský geriatrický kongres a 34. Gressnerove dni, no. 15, pp. 12-17.

21. Meijers JM, van Bokhorst-de van der Schueren MA, Schols JM, Soeters PB, Halfens RJ (2010). Defining malnutrition: mission or mission impossible? Nutrition 26(4): 432-440. DOI: 10.1016/j.nut.2009.06.012.

22. Mikula J, Hluchová L (2005). Parenterálna a enterálna výživa. Via practica 2(5): 253-255.

23. Mink M, Evans A, Moore CG, Calderon KS, Deger S (2010). Nutritional imbalance endorsed by televised food advertisements. J Am Diet Assoc 110(6): 904-910. DOI: 10.1016/j.jada.2010.03.020.

24. Nakanishi N, Hino Y, Ida O, Fukuda H, Shinsho F, Tatara K (1999). Associations between self-assessed masticatory disability and health of community-residing elderly people. Community Dent Oral Epidemiol 27(5): 366-371. DOI: 10.1111/j.1600-0528.1999.tb02033.x.

25. Rentero Redondo L, Iniesta Navalón C, Gascón Cánovas JJ, Tomás Jimenez C, Sánchez Álvarez C (2015). Malnutrition 
in the elderly patient to hospital admission, an old problem unsolved. Nutr Hosp 32(5): 2169-2177. DOI: 0.3305/ nh.2015.32.5.9712.

26. Sobotka L, Allison SP, Fürst R, Meier M, Pertkiewicz L (2004). Basics in clinical nutrition. Prague: Galen.

27. Soenen S, Chapman IM (2013). Body weight, anorexia, and undernutrition in older people. J Am Med Dir Assoc 14(9): 642-648. DOI: 10.1016/j.jamda.2013.02.004.

28. Stratton RJ, King CL, Stroud MA, Jackson AA, Elia M (2006). "Malnutrition Universal Screening Tool" predicts mortality and length of hospital stay in acutely ill elderly. Br J Nutr 95(2): 325-330. DOI: 10.1079/BJN20051622.

29. Sullivan DH, Sun S, Walls RC (1999). Protein-Energy Undernutrition Among Elderly Hospitalized Patients. A Prospective Study. JAMA 281(21): 2013-2009. DOI: 10.1001/ jama.281.21.2013.

30. Svačina Š, et al. (2010). Poruchy metabolizmu a výživy. Praha: Galén.

31. Tannen A, Lohrmann C (2013). Malnutrition in Austrian hospital patients. Prevalence, risk factors, nursing interventions, and quality indicators: a descriptive multicentre study. J Adv Nurs 69(8): 1840-1849. DOI: 10.1111/jan.12051.
32. Teixeira IX, Lopes MV, Martins LC, Diniz CM, de Menezes AP, Alves NP (2016). Validation of clinical indicators of imbalanced nutrition: less than body requirements in early childhood. J Pediatr Nurs 31(2): 179-186. DOI: 10.1016/j. pedn.2015.02.011.

33. Thompson LV (2009). Age-related muscle dysfunction. Exp Gerontol 44(1-2): 106-111. DOI: 10.1016/j.exger.2008.05.003.

34. van Der Pols-Vijlbrief R, Wijnhoven Ha, Schaap La, Terwee Cb, Visser M (2014). Determinants of protein-energy malnutrition in community-dwelling older adults: a systematic review of observational studies. Ageing Res Rev Nov 18: 112-131. DOI: 10.1016/j.arr.2014.09.001.

35. Vanderwee K, Clays E, Bocquaert I, Gobert M, Folens B, Defloor T (2010). Malnutrition and associated factors in elderly hospital patients: a Belgian cross-sectional, multi-centre study. Clin Nutr 29(4): 469-476. DOI: 0.1016/j.clnu.2009.12.013.

36. Wilhelm Z (2001). Výživa v onkológii. Brno: IDVPZ.

37. Zadák Z (2004). Metabolizmus a výživa v starobe. In: Kalvach Z, Zadák Z, Jirák R, Zavázalová H, Sucharda P, et al. (Eds). Geriatria a gerontológia. Praha: Grada Publishing, pp. 298-331.

38. Zeleníková R, Žiaková K (2010). Validizačné štúdie ošetrovatel'ských diagnóz. Ošetřovatelství a porodní asistence 1(1): 1-9. 